\title{
Epidemiological Study of Ground-waterborne Norovirus GI.3-associated Gastroenteritis Outbreaks in Gyeonggi Province of South Korea in May 2011
}

\author{
Myung-Jin Lee ${ }^{1,2}$, Woon-Ho Kim ${ }^{1}$, Han-Gil Cho ${ }^{1}$ and Sang-Seob Lee ${ }^{2 *}$ \\ ${ }^{1}$ Gyeonggi-do Institute of Health \& Environment 95, Pajangcheon st, Jangan-gu, Suwon-city, Gyeonggi-do; ${ }^{2}$ Department \\ of Biology, Kyonggi University Graduate School 94-6, Iui-dong Yeongtong-gu, Suwon-city, Gyeonggi-do, Korea
}

In May 2011, five consecutive gastroenteritis outbreaks were reported at schools in Gyeonggi-do. Epidemiological inspection revealed that one food manufacture company provided 'Kimchi', a traditional Korean side-dish, to these five schools for catering services. Fecal specimens were collected from students and food-handlers to determine causative viral agents. Norovirus genogroup GI was detected from 58 samples out of total 239 specimens by reverse-transcription (RT)-PCR, whereas norovirus GII was found only from one sample. Epidemiological studies also revealed that the Kimchi was processed using groundwater in the food manufacture company. Four groundwater samples were collected from the company and around the area. Norovirus GI was detected from three samples. To determine the norovirus genotypes of positive specimens from clinical and groundwater samples, sequencing and phylogenetic analyses were performed. The genogroup GI from 58 clinical and three groundwater samples and the GII from one food-handler were identified as norovirus GI.3 and GII.18, respectively. Sequence alignment analysis with norovirus GI.3 isolates revealed that identity between clinical and groundwater samples was over than $99.1 \%$ in nucleotide level. In conclusion, norovirus GI.3-contaminated groundwater caused the gastroenteritis outbreaks of five schools, through Kimchi. This molecular epidemiological study was an important report in Korea that clearly identified all transmission routes of norovirus GI.3.

Key Words: Gastroenteritis, Outbreak, Norovirus, Goundwater

\section{서 론}

노로바이러스는 전 세계적으로 수인성·식품매개성 장 관감염증의 주요 원인체로 전 연령층에서 검출되며, 집단 식중독의 중요한 원인체로 알려져 있다 (1 4). 노로바이 러스는 사람의 장내에서 증식하여 분변과 함께 체외로 배출되며 물과 음식, 토양을 통해 다시 사람으로 전파되 는 분변-구강 전파 경로를 거치며 $(2,5 \sim 7)$, 바이러스에

Received: May 15, 2012/ Revised: July 25, 2012

Accepted: August 7, 2012

* Corresponding author: Sang-Seob Lee. Department of Biology, Kyonggi University Graduate School, 94-6 Iui-dong Yeongtong-gu, Suwon-city, Gyeonggi-do, 433-760, Korea.

Phone: +82-31-250-2560, Fax: +82-31-250-2569

e-mail: lmjin@gg.go.kr
감염된 환자로부터 체외로 배출된 바이러스 입자가 적절 한 처리를 거치지 않고 하천이나 지하수에 유입되어 오 염시킬 수 있으며, 이러한 바이러스는 어린이나 노인 등 면역체계가 약한 사람들에게 치명적일 수 있다 $(1,8,9)$.

노로바이러스는 Caliciviridae에 속하는 $27 \mathrm{~nm}$ 크기의 구형 바이러스로서 7.5 7.7 kb의 single-stranded positivesense RNA 바이러스이며, 3 개의 open reading frame (ORF) 이 존재한다 $(10,11)$. ORF1은 helicase, VPg, protease, polymerase를, ORF2는 캡시드(capsid) 단백질을, ORF3는 $\mathrm{ORF} 2$ 에 의해 합성된 캡시드 단백질의 안정화를 위한 보 조적인 역할을 수행하는 구조단백질을 각각 전사하는 것 으로 알려져 있다 $(10,12 \sim 14)$. 노로바이러스는 유행하는 바이러스주 간에 많은 유전적 변이가 보고되어, 이러한 변이를 근거로 유전적 유연관계에 관한 연구가 많이 보 
고되었다 $(2,15)$. 특히, capsid 부위와 RNA dependent RNA polymerase $(\mathrm{RdRp})$ 의 조성에 따라 다양한 유전자형으로 분류되며, 대부분의 인체 감염은 GI형, GII형에 의한 것 으로 알려져 있다 $(2,3)$. 유전자형은 변이 정도에 따라 GI형은 14종, GII형은 18종의 유전자형으로 알려져 있다 $(16,17)$.

노로바이러스는 크기가 작아 토양침투가 쉽고, 저온이 유지되는 지하수에서 장기간 생존 가능성이 있다 (18). 수 돗물의 경우 정수처리기준에 따라 바이러스를 $99.99 \%$ 이상 소독-제거하기 때문에 바이러스에 대해 안전하나 일반적으로 지하수의 경우 소독처리 및 관리가 미흡하여 감염사고 발생의 위험성이 있는 것이 사실이다 (18). 국 가지하수 정보센터에 의하면 2008년 기준 우리나라 지하 수 이용량은 38 억 $\mathrm{m}^{3} /$ 년, 지하수 개발·이용 시설 수는 약 130 만공이며, 이용량은 생활용, 농업용이 거의 비슷한 수 준으로 대부분을 차지하고 있으며, 물 이용량이 많은 사 업장 중 식품제조·가공업소의 경우 상수도 급수지역에 위치해 있더라도 자체 지하수를 개발해 이용하고 있다. 국내는 정수처리장에서 처리된 수질의 향상으로 인하여 물에서 기인하는 질병 발생은 감소하고 있으나, 농촌지역 에서는 식수원으로 지하수가 많이 사용되고 있다. 지하 수는 잠재적인 오염우려가 있고, 다양한 방법으로 오염된 병원균은 수인성 발생의 원인으로 작용하며, 오염된 지하 수에 의한 급성위장염의 발생은 보고되고 있다 $(3,19,20)$.

본 연구는 경기도에서 2011년 5월 18일에서 20일까지 연이어 경기지역 5 개 초·중·고교에서 발생한 급성위장 관염 집단 발생에 대한 역학적 조사결과이다. 초기 역학 조사 결과, 동일한 업체에서 납품한 김치를 급식으로 제 공한 공통점을 발견하여 김치를 제조한 식품업체에서 식 품용수로 사용 중인 지하수를 분석한 결과 노로바이러스 GI.3이 검출되었고 학생 및 조리종사자에 대한 검사결과 동일한 유전자형의 노로바이러스 GI.3이 검출되었다. 본 연구는 수인성 식품매개성 집단 장염 발병의 원인체와 매개체를 확인한 중요한 역학적 연구결과로, 식중독의 사 전 차단 및 확산방지 등 감염병 예방 대책 수립을 위한 좋은 기초자료가 될 수 있을 것이라 예상한다.

\section{재료 및 방법}

\section{역학조사}

경기도내 지리적으로 인접한 수원, 용인, 광주 등 3 개
시의 5 개 학교에서 신고가 접수되어 역학조사에 착수하 였고, 451 명의 환례를 확인하여 환자-대조군 연구를 이용 한 역학조사를 수행하였다. 환례의 정의는 구토, 하루 최 대 3회 이상의 설사 및 기타 동반증상(복통, 발열, 오한, 구역감, 두통) 3 개 이상을 호소하는 것으로 하였다.

\section{환자검체 수집 및 검체 처리}

본 연구에서는 2011년 5월 18일에서 20일까지 5개 초·중·고교에서 신고된 급성위장관염 집단 발생을 통 해 수집된 분변 가검물 149 건과 학교 및 식품제조업체 조리종사자 분변 90 건으로 총 239건의 가검물을 조사하 였다. 학생의 경우 유증상자 중심으로 시료채취를 하였고 조리종사자의 경우 수인성·식품매개질환 역학조사지침 에 의해 전원을 대상으로 검체를 채취하였다. 분변 $1 \mathrm{~g}$ 을 멸균된 $0.1 \mathrm{M}$ phosphate buffered saline (PBS) $9 \mathrm{ml}$ 에 넣어 3 분간 vortex한 후 $4^{\circ} \mathrm{C}, 3,000 \mathrm{rpm}$ 에서 30 분간 원심분리 (Eppendorf, Hamburg, Germany)하여 상층액을 취해 새로 운 튜브에 옮겨 소분한 뒤 노로바이러스 검출에 사용할 때까지 $-70^{\circ} \mathrm{C}$ 에서 보관하였다. 바이러스 $\mathrm{RNA}$ 추출은 분 변 부유액 $200 \mu \mathrm{l}$ 에 Tri-zol (Carlsbad, CA, USA) $600 \mu \mathrm{l}$ 를 첨가하여 30 초간 vortex한 후, 5 분간 실온에서 방치하고, 여기에 chloroform (Sigma, St.Louis, MO, USA) $200 \mu \mathrm{l}$ 를 첨 가하여 30 초간 vortex 하였다. 10 분간 실온에 방치한 다음 $14,000 \mathrm{rpm}$ 으로 $4^{\circ} \mathrm{C}$ 에서 15 분간 원심분리 하였다. 상층액 을 취하여 동량의 isopropyl alcohol (Sigma)을 넣고 혼합 한 후 $-20^{\circ} \mathrm{C}$ 에서 2 시간 이상 방치 후 $14,000 \mathrm{rpm}$ 으로 $4^{\circ} \mathrm{C}$ 에서 30 분간 원심분리 하여 상층액을 제거한 다음 $70 \%$ 에탄올 $800 \mu \mathrm{l}$ 를 첨가하고 10 분간 $4^{\circ} \mathrm{C}$ 에서 $14,000 \mathrm{rpm}$ 으 로 원심분리하여 세척하였다. 상층액을 제거하고 20 분간 실온에서 건조시킨 후 $\mathrm{DEPC}$-처리 증류수 $30 \mu \mathrm{l}$ 에 녹인 RNA를 RT-PCR을 위한 주형으로 사용하였다.

환경검체 수집 및 검체 처리

본 연구에서는 오염 경로를 파악하기 위하여 급성위장 관염 집단 발생과 관련된 식품업체에서 식품용수로 사용 하는 지하수 2 건과 인접지역 지하수 2 건을 사용하였다.

\section{세균학적 분석}

세균학적 분석은 먹는물 수질공정시험기준에 따라 수 행하였으며, 일반세균과 총대장균군 및 분원성대장균군 분석으로 나누어 진행하였다. 일반세균분석은 중온세균분 
Table 1. The oligonucleotides used for the detection of noroviruses

\begin{tabular}{cllll}
\hline \hline Genotype & Primer & \multicolumn{1}{c}{ Sequence $\left(5^{\prime} \rightarrow 3^{\prime}\right)$} & \multicolumn{1}{c}{ Position } & \multicolumn{1}{c}{ Application } \\
\hline \multirow{2}{*}{ I } & Gl-F1M & CTGCCCGAATTYGTAAATGATGAT & $5342^{\mathrm{a}}$ & \multicolumn{1}{c}{ Onestep RT PCR } \\
& GI-R1M & CCAACCCARCCATTRTACATYTG & $5671^{\mathrm{a}}$ & Onestep RT PCR/Seminested PCR \\
& GI-F2 & ATGATGATGG CGTCTAAGGA CGC & $5357^{\mathrm{a}}$ & Seminested PCR \\
& GII-F1M & GGGAGGGCGA TCGCAATCT & $5058^{\mathrm{b}}$ & Onestep RT PCR \\
II & GII-R1M & CCRCCIGCATRICCRTTRTACAT & $5401^{\mathrm{b}}$ & Onestep RT PCR/Seminested PCR \\
& GII-F3 & TTGTGAATGAAGATGGCGTCGART & $5088^{\mathrm{b}}$ & Seminested PCR \\
\hline
\end{tabular}

${ }^{\mathrm{a}}$ GeneBank accession number M87661, ${ }^{\mathrm{b}}$ GeneBank accession number X86557.

석법을 사용하였으며, 시료 $1 \mathrm{ml}$ 을 $12 \mathrm{ml}$ 의 $1.5 \%$ Plate count agar (Oxoid, Basingstoke, HA, England)와 잘 섞어 부어 상온에서 한천이 굳을 때까지 30 분 방치한 뒤 $35 \pm$ $0.5^{\circ} \mathrm{C}$ 에서 $48 \pm 2$ 시간 동안 배양하여 계수하였다.

총대장균군은 시험관법을 사용하였으며, 추정시험은 $2 \times$ Lactose broth (Oxoid)를 사용하여 10개에 시료 $10 \mathrm{ml}$ 씩 접종하여 $35 \pm 0.5^{\circ} \mathrm{C}$ 에서 $48 \pm 3$ 시간 배양하여 다람시험 관에서 기체 발생이 없을 때에는 추정시험 음성으로 판 정하고, 하나 이상의 시험관에서 기체 발생이 관찰되었 을 때 확정시험을 실시하였다. 확정시험은 Brilliant green lactose bile (BGLB) (Oxoid)를 사용하여 추정시험에서 기 체가 발생한 모든 시험관으로부터 배양액을 1 백금이씩 취하여 확정시험용 배지가 $10 \mathrm{ml}$ 씩 들어있는 시험관에 각 각 접종하여 $35 \pm 0.5^{\circ} \mathrm{C}$ 에서 $48 \pm 3$ 시간 배양하였다. 이때 기체가 발생하지 않으면 음성으로 판정하고 기체 발생 이 관찰되었을 때는 총대장균군 양성으로 판정하였다.

분원성대장균군은 총대장균군 시험관법 추정시험에서 기체가 발생되었거나 증식이 많은 시험관 또는 산을 생 성한 모든 시험관에 대하여 지름 $3 \mathrm{~mm}$ 의 백금이를 사용, 무균조작으로 확정시험용 $\mathrm{EC}$ 배지(Oxoid)가 든 시험관에 이식하여 $44.5 \pm 0.2^{\circ} \mathrm{C}$ 의 항온수조에서 $24 \pm 2$ 시간 배양하 였다. 이때 기체 발생을 관찰할 수 없으면 분원성대장균 군 음성, 기체 발생이 관찰되었을 때는 분원성대장균군 양성으로 판정하였다.

\section{바이러스 농축 및 핵산의 추출}

바이러스의 탈리와 농축과정은 US EPA의 Information Collection Rule (ICR)을 따랐다. 지하수 500 600 liter를 양 전하로 하전된 $1 \mathrm{MDS}$ 필터(10-inch-pore- size, CUNO Inc. Meriden, $\mathrm{CT}, \mathrm{USA}$ )에 통과시켜 바이러스를 흡착시켰다.
부착된 바이러스를 $1.5 \%$ beef extract가 함유된 $\mathrm{pH} 9.5$ $0.05 \mathrm{M}$ glycine buffer를 이용해 탈리했다. 탈리한 용액을 $1 \mathrm{M} \mathrm{HCl}$ 을 이용하여 $\mathrm{pH}$ 3.4 3.6로 맞춘 후, 30 분 동안 재응집시키고, $4{ }^{\circ} \mathrm{C} \quad 2,500 \times \mathrm{g}$ 에서 15 분간 원심분리하였 다. 얻어진 응집물(pellets)은 $0.15 \mathrm{M}$ sodium phosphate $(\mathrm{pH}$ 9.5) $25 \mathrm{ml}$ 을 이용하여 재부유 시킨 후, 10 분간 방치하였 다. $9,000 \times \mathrm{g}$ 에서 10 분간 원심분리한 후, 상층액을 취했 다. $1 \mathrm{M} \mathrm{NaOH}$ 을 이용하여 $\mathrm{pH}$ 7.0으로 맞추고, 농축액을 0.2- $\mu \mathrm{m}$-pore-size의 필터(Pall Gelman Laboratory, Ann Arbor, MI. USA)를 통과시킨다. 환경검체에서의 바이러스 RNA 추출은 QIAamp microspin columns (viral RNA mini kit: QIAGEN, Hilden, Germany)을 이용하였으며, 추출된 RNA 는 사용할 때까지 $-70^{\circ} \mathrm{C}$ 에서 보관하였다.

$$
\text { 노로바이러스 유전자 검출 }
$$

$$
\text { One-step RT-PCR }
$$

노로바이러스 유전자 검출을 위해 Kojima 등 (21)이 보고한 노로바이러스 검출용 primer를 사용하였다(Table 1). RT-PCR QC를 위하여 Lee 등 (22)이 보고한 양성대조 군을 사용하여 한 시료당 2 회의 실험과정을 반복하였다.

One-step RT-PCR를 위해 2X RT-PCR Master mix $12.5 \mu \mathrm{l}$, 10 pmole sense primer와 antisense primer 각각 $2 \mu \mathrm{l}$, DW 6 $\mu \mathrm{l}$, RNA $2 \mu \mathrm{l}$ 를 포함한 $25 \mu \mathrm{l}$ 반응액을 사용하였다. 유전 자 증폭을 위해 thermcycler (GeneAmp PCR system 9700, Applied Biosystems, NY, USA)를 이용하여 $48^{\circ} \mathrm{C}$ 에서 40 분 간 $\mathrm{RT}$ 를 수행하고, $94^{\circ} \mathrm{C} 3$ 분 동안 반응시킨 뒤 $94^{\circ} \mathrm{C} 30$ 초, $54^{\circ} \mathrm{C} 30$ 초, $72^{\circ} \mathrm{C} 45$ 초로 $35 \mathrm{cycles}$ 를 반복한 후 $72^{\circ} \mathrm{C}$ 에 서 7 분간 반응을 수행하였다. 
Semi-nested RT-PCR

RT-PCR 후 얻은 산물 $2 \mu 1$ 를 이용하여 semi-nested RT-PCR을 수행하였으며 PCR reaction buffer, $2.5 \mathrm{mM}$ dNTP, 20 pmol primer, 1 U Taq polymerase (Bioneer, Daejeon, Korea)이 포함된 $50 \mu \mathrm{l}$ 반응액을 제조한 후 실험에 사 용하였다. 반응조건은 $94^{\circ} \mathrm{C}$ 에서 3 분 동안 반응시킨 후 $94^{\circ} \mathrm{C} 30$ 초, $56^{\circ} \mathrm{C} 30$ 초, $72^{\circ} \mathrm{C} 45$ 초로 25 cycles를 반복한 후 $72^{\circ} \mathrm{C}$ 에서 7 분간 반응을 수행하였다. $\mathrm{PCR}$ 산물은 $1 \% \mathrm{LE}$ agarose gel (Gibco, Grand island, CA, USA)에 전기영동한 후, ethidium bromide (Bioneer)에 염색하여 UV 하에서 관 찰하여 특이적인 크기의 band를 확인하였다.

\section{노로바이러스 유전자형 분석}

\section{$\mathrm{PCR}$ 산물의 정제}

증폭된 PCR 산물은 $1 \%$ 아가로즈 젤 $(\mathrm{Gibco}$ 로 전기영 동 하여 확인한 뒤, $\mathrm{DNA}$ 절편을 절단하고, Gel Purification kit (Bioneer)를 사용하여 정제하였다. 절편을 3 배 부피의 젤 용해용 완충용액(Buffer $\mathrm{GB})$ 을 첨가하고 $50^{\circ} \mathrm{C}$ 에서 젤 을 용해시킨 뒤, spin column으로 옮겨 $4^{\circ} \mathrm{C}$ 에서 14,000

Table 2. Attack rate of gastroenteritis outbreaks occurred in Gyeonggi in 2011

\begin{tabular}{|c|c|c|c|c|}
\hline $\begin{array}{c}\text { Date of } \\
\text { outbreaks }\end{array}$ & School & Total & Patient & $\begin{array}{c}\text { Attack rates } \\
(\%)\end{array}$ \\
\hline 5.18 & A & 1,658 & 107 & 6.5 \\
\hline 5.19 & B & 1,676 & 47 & 2.8 \\
\hline 5.20 & $\mathrm{C}$ & 1,266 & 57 & 4.5 \\
\hline 5.20 & D & 1,612 & 212 & 13.2 \\
\hline 5.20 & E & 1,393 & 28 & 2.0 \\
\hline \multicolumn{2}{|c|}{ Total } & 7,605 & 451 & 5.9 \\
\hline
\end{tabular}

$\mathrm{rpm}$ 으로 1 분간 원심한 후, 세척용 완충용액 $750 \mu \mathrm{l}$ 을 첨 가하고 $14,000 \mathrm{rpm}$ 에서 1 분간 원심한다. 상층액을 취하여 잔여 세척용 완충용액을 제거하고 $30 \sim 50 \mu \mathrm{l}$ 의 증류수로 $\mathrm{DNA}$ 를 회수하여 다음 실험에 이용하였다.

\section{Automatic Sequencing}

염기서열 분석은 전문 업체(Macrogen, Seoul, Korea)에 의뢰하여 수행하였다. 간단히 서술하면, $\mathrm{PCR}$ 을 통해서 증폭된 노로바이러스 양성 $\mathrm{PCR}$ product를 이용하여 각각 의 유전자형에 특이적인 프라이머를 사용하여 양쪽 방향 으로 dideoxynucleotide chain termination 기법을 사용하는 Bigdye sequencing kit (ABI prism Applied Biosystems, Perkin Elmer, Boston USA)을 사용하여 sequencing reaction을 하였 다. 얻어진 산물을 Bigdye removal kit (Amersham Pharmacia, England)로 정제한 뒤, automated DNA sequencer (model 377; Applied Biosystems, Boston, USA)로 염기서열 분석을 하였다.

\section{Phylogenetic Analysis}

분석된 염기서열은 DNAstar (Madison, USA) 프로그램을 통해 염기서열의 결정 및 비교분석을 수행하였고, 기존 에 보고된 외국의 노로바이러스 주를 이용하여 DNAStar program (version 5.03)의 Clustal W를 이용하여 alignment 를 수행하였으며 계통발생학적 분석은 neighbor-joining method을 이용하였다.

결 과

\section{환자발생 현황 및 환자군 특성}

환례 정의에 따른 학생 환자 발생은 총 노출인원 7,605 중 451명(발병률 $5.9 \%$ ) 이었다. 각 학교별 발병률

Table 3. Clinical characteristics of patients from gastroenteritis outbreak occurred in Gyeonggi in 2011

\begin{tabular}{|c|c|c|c|c|c|}
\hline \multirow{2}{*}{ No. of patients (\%) } & A & $\mathrm{B}$ & $\mathrm{C}$ & $\mathrm{D}$ & $\mathrm{E}$ \\
\hline & 107 & 47 & 57 & 212 & 28 \\
\hline Diarrhea & $82(76.6 \%)$ & $37(78.7 \%)$ & $36(63.2 \%)$ & $163(76.9 \%)$ & $23(85.2 \%)$ \\
\hline Vomiting & $51(47.7 \%)$ & $27(57.4 \%)$ & $42(73.7 \%)$ & $102(48.1 \%)$ & $22(78.6 \%)$ \\
\hline Stomachache & $84(78.5 \%)$ & $38(80.9 \%)$ & $30(52.6 \%)$ & $143(67.5 \%)$ & $20(71.4 \%)$ \\
\hline Fever & $40(37.4 \%)$ & $21(44.7 \%)$ & $12(21.1 \%)$ & $51(24.1 \%)$ & $6(21.4 \%)$ \\
\hline Rigor & $45(42.1 \%)$ & $19(40.4 \%)$ & $16(28.1 \%)$ & $81(38.2 \%)$ & $5(17.9 \%)$ \\
\hline
\end{tabular}


은 Table 2과 같으며, 환례에 해당하는 환자의 증상은 학 교별로 다소 차이를 보이고 있으나, 설사와 복통이 가장 흔한 증상이었고, 구토를 호소하는 학생도 $50 \%$ 를 넘기고 있었다. 학교별 증상 호소 양상은 Table 3와 같았다. 환자 의 연령별 분포는 8 13세 57 명(12.6\%), 14 16세 240명 (53.2\%), 17 19세 154명(34.1\%)이었다.

\section{환자검체에서의 노로바이러스 검출}

2011년 5월 18 일에서 20 일까지 경기도내 5 개 초. 중. 고교에서 신고된 급성위장관염 집단 발생을 통해 수집된 설사분변 가검물 149 건과 학교 및 식품제조업체 조리종 사자 분변 90 건 등 총 239 건 중 59건(24.7\%)에서 노로바 이러스가 양성으로 확인되었다. 59건의 검체로부터 추출
한 RNA를 이용하여 노로바이러스 GI과 GII에 대한 onestep RT-PCR과 semi-nested PCR을 각각 수행하여 58건에 서 GI형, 식품제조업체 조리종사자 시료 1건에서 $\mathrm{GII}$ 형에 특이적인 노로바이러스의 유전자를 확인하였다(Table 4).

검사결과 학생의 경우 149 건 중 51 건(34.2\%)에서 노 로바이러스가 검출되었으며, 학교별 양성율은 $\mathrm{A}$ 교 12건 (40.0\%), B교 10건(34.5\%), C교 11건(36.7\%), D교 7건 $(25.0 \%)$, E교 11건(34.4\%)로 나타났다. 학교급식 및 식품 제조업체 조리종사자는 90 건 중 8 건( $8.9 \%$ )에서 노로바이 러스가 검출되었으며, 식품제조업체 2건(9.1\%), D교 6건 $(54.5 \%)$ 으로 나타나 조리종사자의 경우 $\mathrm{D}$ 교에서만 노로 바이러스가 검출되었다(Table 4).

Table 4. Incidence of norovirus isolated in gastroenteritis outbreak occurred in Gyeonggi in 2011

\begin{tabular}{|c|c|c|c|c|c|c|}
\hline \multirow{2}{*}{ School } & \multirow{2}{*}{ No. of total isolates } & \multirow{2}{*}{ Isolates type } & \multirow{2}{*}{ No. of isolates } & \multirow{2}{*}{ No. of positive (\%) } & \multicolumn{2}{|c|}{ Genotype } \\
\hline & & & & & GI-3 & G II-18 \\
\hline Total & 239 & & 239 & $59(24.7 \%)$ & 58 & 1 \\
\hline \multirow{2}{*}{ A } & \multirow{2}{*}{44} & Students & 30 & $12(40.0 \%)$ & 12 & \\
\hline & & Food handlers & 14 & $0(-)$ & & \\
\hline \multirow{2}{*}{ B } & \multirow{2}{*}{47} & Students & 29 & $10(34.5 \%)$ & 10 & \\
\hline & & Food handlers & 18 & $0(-)$ & & \\
\hline \multirow{2}{*}{$\mathrm{C}$} & \multirow{2}{*}{43} & Students & 30 & $11(36.7 \%)$ & 11 & \\
\hline & & Food handlers & 13 & $0(-)$ & & \\
\hline \multirow{2}{*}{$\mathrm{D}$} & \multirow{2}{*}{39} & Students & 28 & $7(25.0 \%)$ & 7 & \\
\hline & & Food handlers & 11 & $6(54.5 \%)$ & 6 & \\
\hline \multirow{2}{*}{$\mathrm{E}$} & \multirow{2}{*}{44} & Students & 32 & $11(34.4 \%)$ & 11 & \\
\hline & & Food handlers & 12 & $0(-)$ & & \\
\hline $\mathrm{F}^{\mathrm{a}}$ & 22 & Food handlers & 22 & $2(9.1 \%)$ & 1 & 1 \\
\hline
\end{tabular}

${ }^{\mathrm{a}}$ food manufacture

Table 5. Food items associated with increased risk of norovirus infection

\begin{tabular}{ccclcc}
\hline \hline School & No. of patients & No. of control subjects & Food item & Adjusted odds ratio (95\% CI) & $p$-value \\
\hline \multirow{2}{*}{ A } & 50 & 179 & Kkakdugi & $2.98(1.004 \sim 8.83)$ & 0.049 \\
& 57 & 119 & Baechu-kimchi & $2.56(1.07 \sim 6.09)$ & 0.034 \\
\multirow{2}{*}{ D } & 212 & 774 & Baek-kimchi & $1.66(1.07 \sim 2.57)$ & 0.023 \\
& 28 & & Baechu-kimchi & $1.65(1.04 \sim 2.63)$ & 0.033 \\
E & \multirow{2}{*}{24} & Baek-kimchi & $4.55(1.55 \sim 17.22)$ & 0.005 \\
\hline
\end{tabular}

CI: confidence interval 


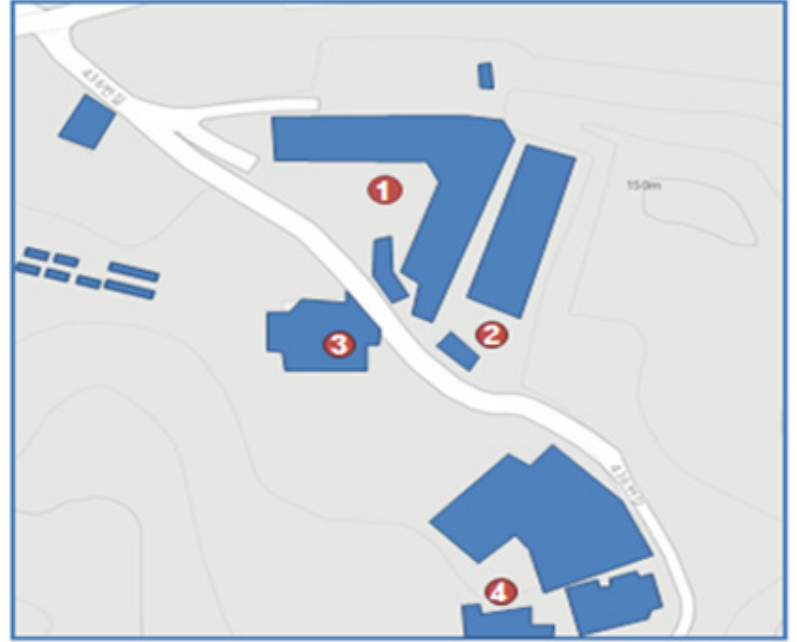

Figure 1. Locations of groundwater sampling points. Groundwater of (1) and (2) points used in food manufacturing. Ground water of (3) and (4) points used to determine the area of groundwater-contamination.

\section{환경검체에서의 세균 및 노로바이러스 검출}

5 개 학교의 동시 유행이 인지되면서, 이들의 연관성을 찾기 위해 식자재 납품업체들을 조사하였다. 조사결과 5 개 학교는 모두 직영으로 운영되고 있었으며 김치류 납 품업체가 동일하다는 공통점을 발견하여 환자-대조군 분 석을 통한 식단에 따른 위험요인을 분석하였다. 분석결과 $\mathrm{A}$ 교는 깍두기와 배추김치 $\mathrm{D}$ 교는 백김치와 배추김치 $\mathrm{E}$ 교 는 백김치가 위험요인으로 지목되었으며 B·C교는 위험 요인을 지목할 수 없었다(Table 5).

역학조사 결과 김치 납품업체는 지하수를 식품용수로 김치를 제조하고 있었으므로 Fig. 1과 같이 관련 식품업 체에서 식품용수로 사용 중인 지하수 2건과 오염 경로를 파악하기 위한 인접지역 지하수 2 건을 채수하였다. 식품 업체와 인근지역은 오수처리시설이 3곳 있었으며 우수 관에 연결된 곳도 있었다. 총 4건의 검체로부터 추출한 RNA를 이용하여 노로바이러스 GI과 GII에 대한 one-step RT-PCR과 semi-nested PCR을 각각 수행하여 3건에서 GI 형에 특이적인 노로바이러스의 유전자를 확인하였고, 4 개 의 시료 중 식품용수로 사용된 2 개의 시료에서 $100 \mathrm{cfu} /$ $\mathrm{ml}$ 의 일반세균 허용기준을 초과하였으며, 총대장균군, 분 원성대장균군이 모두 검출되어 식품공전 기준인 식품제 조·가공 및 조리에 사용하는 물은 먹는물관리법의 먹는 물수질기준에 적합한 것이어야 한다는 기준에 부적합 한
Table 6. Detection of bacterial indicators in groundwater samples

\begin{tabular}{ccccc}
\hline \hline Site & $\begin{array}{c}\text { Total colony } \\
\text { counts } \\
(\mathrm{CFU} / \mathrm{ml})\end{array}$ & $\begin{array}{c}\text { Total } \\
\text { coliforms } \\
(/ 100 \mathrm{ml})\end{array}$ & $\begin{array}{c}\text { Fecal } \\
\text { coliforms } \\
(/ 100 \mathrm{ml})\end{array}$ & $\begin{array}{c}\text { Norovirus } \\
\text { detection }\end{array}$ \\
\hline (1) & 800 & + & + & GI \\
$(2)$ & 760 & + & + & GI \\
(3) & 0 & - & - & - \\
(4) & 0 & - & - & GI \\
\hline
\end{tabular}

것으로 나타났다. 인접지역 지하수에서는 일반세균, 총대 장균군, 분원성대장균군이 검출되지 않았다(Table 6).

채수지점 (1), (2)는 식품용수로 사용 중인 지하수로 김 치류를 제조하는데 사용되고 있었고 (3), (4)는 오염 경로 를 파악하기 위한 인접지역의 지하수로 (1), (2), (4)에서 노로바이러스가 검출되었다.

\section{노로바이러스 유전자형 분포 양상 및 계통학적 분석}

2011년 5월 경기도내 5개 초·중·고교에서 발생한 집 단 급성위장관염 환자 설사분변에서 검출된 노로바이러 스 양성검체 59건과 식품용수 및 인접지역 지하수에서 검출된 노로바이러스 양성검체 3건 등 총 62 건을 대상으 로 semi-nested PCR 과정을 통해 얻은 최종 생산물의 염 기서열을 분석하였다. 계통유전학적 분석결과, 환자검체 58 건과 지하수 검체 3 건을 포함한 61건에서 GI.3형으로 확인되었으며, 식품제조업체의 조리종사자 검체 1 건에서 GII.18형이 확인되었다. 결과적으로, GI.3형 노로바이러스 가 집단 장염 발생의 원인으로 확인되었다. 유전자 염기 서열 분석결과 경기도 지역 내에서 검출된 노로바이러스 검체 중 Gyeonggi 11-5-08 등 58건의 유전자형은 GI.3형의 Destrshield strain과 $94.4 \%$, 환자로부터 분리된 Gyeonggi 11-5-117, Gyeonggi 11-5-162 2건은 93.9\%, 식품용수로 사용 중인 지하수로부터 분리된 Gyeonggi 11-5-216은 93.4\%의 상동성을 보여주었다(Table 7).

또한, 식중독의 원인으로 예상되는 지하수에 대한 유전 자 검사결과와 매우 높은 상동성을 보여주었고, 집단 식 중독 환자검체 56 건의 염기서열은 지하수 2 건과 $100 \%$ 일치하였다(Fig. 2). 지하수 2건 중 1건은 식품용수로 사 용 중인 지하수였으며, 1 건은 오염 경로를 파악하기 위 한 인접지역 지하수였다. 나머지 3건 시료의 유전자형도 $99.5 \%$ 일치를 보여, 동일한 유전자형의 노로바이러스 검 출을 확인하였다. 결론적으로 노로바이러스에 오염된 지 
Table 7. Comparisons of nucleotides identity among the norovirus GI.3 genotype detected from gastroenteritis outbreak associated patients and groundwater samples

\begin{tabular}{|c|c|c|c|c|c|c|c|c|c|c|c|c|c|c|c|c|c|c|}
\hline & 117 & 162 & 216 & Rest & GI.10 & GI.8 & GI.4 & GI.3 & GI.5 & GI.10 & GI.12 & GI.11 & GI.9 & GI.14 & GI.13 & GI.6 & GI.2 & GI.7 \\
\hline $117^{\mathrm{a}}$ & $* * *$ & 99.1 & 99.1 & 99.5 & 83.6 & 73.7 & 71.8 & 93.9 & 67.1 & 75.1 & 86.9 & 84.5 & 67.6 & 86.9 & 72.3 & 75.1 & 68.5 & 74.6 \\
\hline $162^{\mathrm{b}}$ & & $* * *$ & 99.1 & 99.5 & 82.6 & 72.3 & 71.8 & 93.9 & 65.7 & 74.2 & 86.4 & 83.1 & 66.7 & 86.4 & 71.4 & 74.2 & 68.5 & 73.7 \\
\hline $216^{\mathrm{c}}$ & & & $* * *$ & 99.5 & 82.2 & 72.8 & 70.9 & 93.4 & 66.2 & 74.2 & 86.4 & 83.1 & 66.7 & 86.4 & 71.4 & 74.6 & 67.6 & 73.7 \\
\hline Rest $^{d}$ & & & & $* * *$ & 83.1 & 73.7 & 71.8 & 94.4 & 67.1 & 75.1 & 87.3 & 84 & 67.6 & 87.3 & 72.3 & 75.6 & 68.5 & 74.6 \\
\hline GI.10 & & & & & $* * *$ & 74.4 & 73.1 & 82.3 & 71.8 & 75.4 & 82.2 & 79 & 71.5 & 76.6 & 71.5 & 71.1 & 76.7 & 75.4 \\
\hline GI.8 & & & & & & $* * *$ & 77.7 & 76.7 & 79.3 & 79.3 & 75.6 & 74.2 & 78.4 & 74.9 & 71.5 & 82.6 & 76.7 & 70.2 \\
\hline GI.4 & & & & & & & $* * *$ & 72.1 & 79 & 78 & 74.1 & 73.6 & 80 & 76.3 & 68.8 & 74.4 & 76.7 & 72.8 \\
\hline GI.3 & & & & & & & & $* * *$ & 70.2 & 76.7 & 84.4 & 81.4 & 71.8 & 81.4 & 72.1 & 72.8 & 72.1 & 75.4 \\
\hline GI.5 & & & & & & & & & $* * *$ & 74.8 & 68.1 & 69.8 & 87.2 & 71.5 & 67.8 & 72.5 & 76.1 & 75.4 \\
\hline GI.10 & & & & & & & & & & $* * *$ & 74.4 & 72.2 & 76.4 & 71.2 & 68.5 & 74.8 & 76.7 & 75.1 \\
\hline GI.12 & & & & & & & & & & & $* * *$ & 83.3 & 71.1 & 83 & 71.5 & 74.1 & 73 & 75.6 \\
\hline GI.11 & & & & & & & & & & & & $* * *$ & 70.2 & 80.7 & 70.5 & 71.2 & 72.2 & 76.6 \\
\hline GI.9 & & & & & & & & & & & & & $* * *$ & 71.2 & 71.1 & 72.5 & 77.7 & 74.8 \\
\hline GI.14 & & & & & & & & & & & & & & $* * *$ & 72.2 & 74.6 & 75.9 & 74.6 \\
\hline GI.13 & & & & & & & & & & & & & & & $* * *$ & 64.1 & 68.5 & 72.1 \\
\hline GI.6 & & & & & & & & & & & & & & & & $* * *$ & 73.4 & 66.2 \\
\hline GI.2 & & & & & & & & & & & & & & & & & $* * *$ & 73.4 \\
\hline GI.7 & & & & & & & & & & & & & & & & & & $* * *$ \\
\hline
\end{tabular}

Yellow-box indicated inter-identity between isolates and GI.3 reference strain at nucleotide level.

${ }^{\mathrm{a}}$ Human/Gyeonggi 11-05-117, ${ }^{\mathrm{b}}$ Human/Gyeonggi 11-05-162

${ }^{\mathrm{c}}$ Groundwater/Gyeonggi 11-05-216, $\quad{ }^{\mathrm{d}}$ The rest included the other 56 patients and 2 groundwater samples.

하수에 의한 식중독으로 확인되었다.

\section{고 찰}

노로바이러스의 발생은 주로 학교, 가족, 공동체 등 공 공시설에 폭발적으로 발생하는 비세균성 위장관염의 주 요한 단일 원인체로 (23) 1990년대 후반부터 전 세계적으 로 발생보고 되었으며 (24 26), 국내에서도 식중독으로 인한 산발적 급성위장관염 발생의 많은 원인이 노로바이 러스로 나타났다 (27).

본 연구는 경기지역에서 2011년 5월 18일부터 20일까 지 연이어 5 개 초·중·고교에서 신고된 집단 급성위장관 염 발병을 역학적으로 연구한 결과이다. 역학조사 결과 동일한 업체에서 제조한 김치를 급식으로 제공한 공통점 을 발견하여 식품제조업체에서 식품용수로 사용 중인 지 하수를 대상으로 노로바이러스 감염실태와 유전자형의
분포 양상을 조사하였다. 조사결과 환자와 조리종사자 분 변 239건 중 59건(24.7\%), 지하수 4건 중 3건(75\%)에서 노로바이러스가 확인되었으며, 노로바이러스 양성검체 61 건의 유전자형 분석결과 모두 GI.3형이 유행하였음을 확인하였다. 5 개 학교 모두 1 2일 이내에 대부분의 환례 가 발생하였고, 비교적 짧은 잠복기의 수인성 식품매개 감염병이 의심되는 상황이었으며 검사결과 5 개 학교 모 두 유증상자의 분변에서 노로바이러스 GI.3이 검출되었 고, 공통적으로 동일한 식품회사로부터 납품받는 김치류 를 제공받았다. 이러한 사실들을 바탕으로, 식품제조용수 로 사용 중인 지하수를 검사한 결과 환자와 같은 유전자 형의 노로바이러스 GI.3이 검출되어 개별유행이 아닌 공 통 원인에 의한 유행으로 판단되었다. 한편, 식품의약품 안전청에서는 환자-대조군 연구에서 유의성을 보인 백 김치에서 노로바이러스 GI.3을 검출하였다고 보고하였다. 결론적으로, 2011년 5월 18일에서 20일까지 보고된 경기 


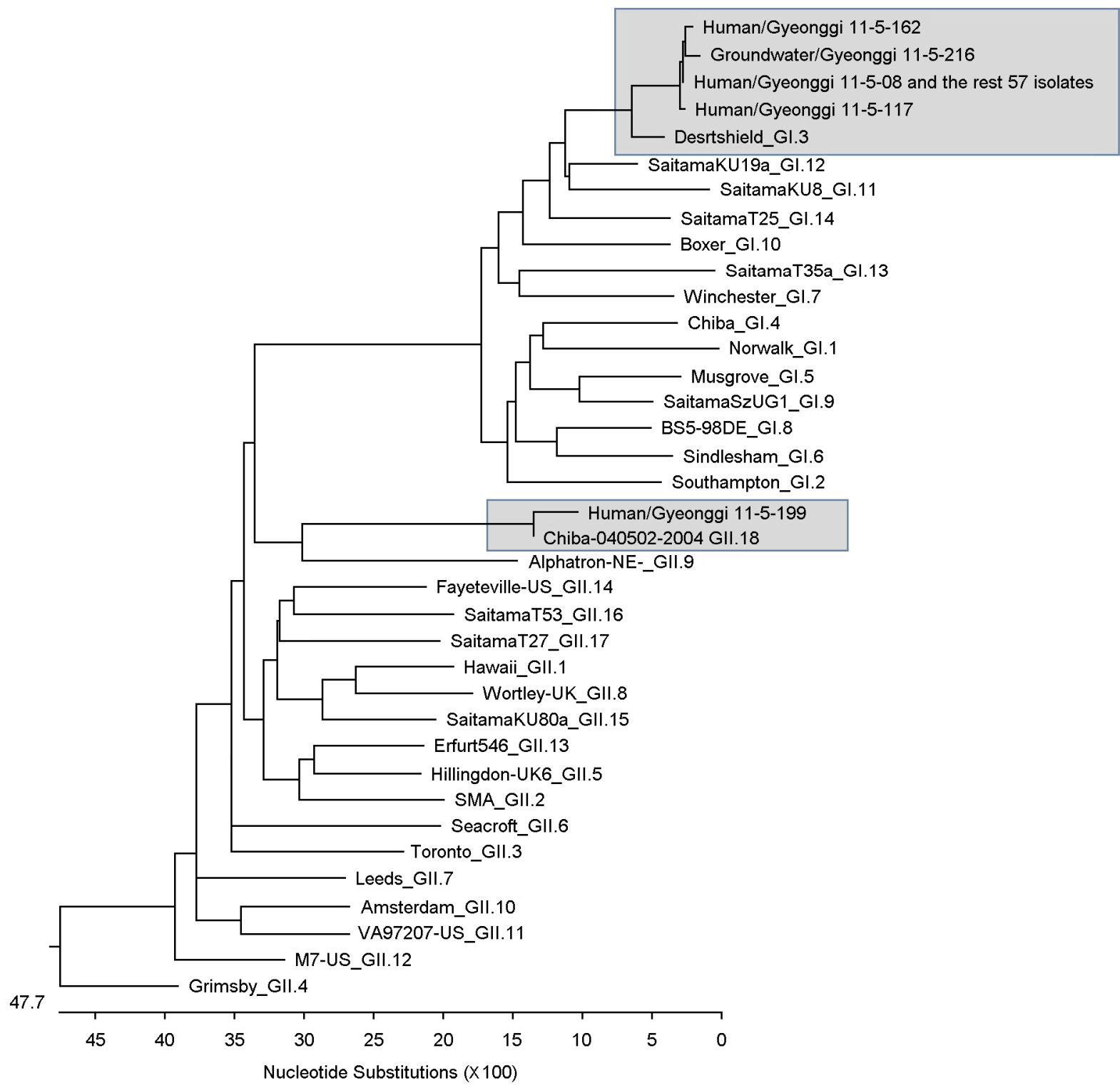

Figure 2. Phylogenetic analysis of the partial capsid sequences of norovirus isolates from gastroenteritis outbreaks in Gyeonggi in 2011.

도 5 개 학교의 집단 설사, 구토 환자 발생은 오염된 지하 수를 이용하여 제조된 김치류를 매개로 한 노로바이러스 GI.3 유행이라고 결론지을 수 있다.

국토해양부 지하수 이용 현황자료에 따르면, 지역별로 경기도가 연간 5 억 5 천만 $\mathrm{m}^{3}$ 을 사용하여 가장 많이 이 용하고 있다. 지하수의 경우 대체수자원 및 보조수자원 으로서의 이용은 점차 증가할 것으로 전망되고 있으나 소독처리 및 관리가 미흡하여 감염사고 발생의 위험성이 있으며, 바이러스성 식중독의 경우 식중독 사고 건수 당 환자수가 대규모인 경우가 많으므로 이에 대한 적극적인
예방 및 관리가 더욱 중요하다 (18). 지하수를 식품용수로 사용하는 학교, 청소년수련원, 사회복지시설의 집단 급식 소 및 위탁급식업소 등에 대한 노로바이러스 집중관리 실시를 하고 있는 식품의약품안전청 자료에 따르면 노로 바이러스 검출율은 2009년 2,032건 중 62건(3.1\%), 2010년 $2,293$ 건 중 18 건( $0.8 \%), 2011$ 년 2,289 건 중 27 건(1.2\%)으로 확인되었고 2009년부터 2011년까지 검출된 노로바이러스 유전자형은 GI형이 29건으로 $24.4 \%$, GII형이 90건으로 $75.6 \%$ 로 나타났으며, 그 중 GII.4형이 57건(48\%)으로 가 장 높게 검출되었다. 전체 노로바이러스 매개 발병의 
75 90\%가 GII형에 의한 것으로 보고된 것과 일치된 양 상을 보였다 $(2,28)$. 그러나 환경에서 검출되는 노로바 이러스의 주요 유전자형은 $\mathrm{GI}$ 형이라는 연구도 확인할 수 있었다 (5). Jung 등 (29)은 처리되지 않은 지하수 39건 중 7건(18\%)에서 노로바이러스 검출을 확인하여, 이 중 $\mathrm{GI}$ 형 5 건(71\%), GII형 2 건(29\%)의 비율로 나타났고, Lee 등 (20)은 경기지역 강을 대상으로 노로바이러스의 유전적 다양성검사결과 총 58 건 중 32 건(55.2\%)에서 노로바이러 스 $\mathrm{GI}$ 형의 검출을 확인하였고, 26건(44.8\%)에서 $\mathrm{GII}$ 형을 확인하였다. 또한, 국내에서 2004년 5월 제주도로 수학여 행을 갔던 고등학생들에게 집단설사가 발생하여 식수와 환자에 대한 바이러스 검사결과 동일유전자형의 노로바 이러스 GI.3형이 검출되었고 (3), 2008년 1월 성남 영어 마을 학생들이 광주에 소재한 $\mathrm{OOOO}$ 에 갔다가 발생한 급성위장염환자에서 노로바이러스 GI.4형이 검출되었고, $\mathrm{OOOO}$ 에서 사용하는 지하수에서도 동일한 유전자형이 확인되어 오염된 지하수를 매개로 발생한 것으로 나타났 다 (30).

국내에서는 집단급식이 증가되면서 식품, 물 등을 매개 로 한 급성위장관염 및 집단 식중독의 빈도가 증가하고 있고, 이에 대한 원인 병원체로 노로바이러스의 공중보건 학적인 중요성이 인식되고 있다 (4). 지하수를 음용수로 사용하여 야기된 노로바이러스 질병 발생의 원인으로는 음용수 사용시설의 인근에 위치한 정화조의 균열과 파손, 하수처리시스템 펌프의 결함 및 기능정지, 그리고 하수의 토양 살포행위 등인 것으로 나타났다 $(31,32)$. 본 연구에 서도 채수지점 인근에 오수처리시설이 3 개소가 있었고 우수관거에 연결된 처리시설도 있어 관리부실로 인한 바 이러스오염으로 추정할 수 있었다.

식품의 제조·가공·조리·세척용수에 의한 노로바이러 스의 질병 발생은 오염된 지하수를 사용함으로써 식품이 오염되고, 오염된 식품을 사람이 섭취함으로써 2 차적인 단계에 의하여 질병을 유발할 수 있다. 그러나 오염된 식 품이 유통과정을 거치고, 사람이 섭취한 후 증상이 나타 나거나 발병하기 때문에 이미 일정 시간이 지나고, 또한 식품에 사용된 원료 식자재의 종류가 매우 다양하여 오 염된 원료 식자재를 분리하고 추적하는 데에 역학조사상 많은 제약과 어려움이 있다. 본 연구에서 노로바이러스에 오염된 식품용수를 사용하여 조리된 식품섭취로 환자가 발생되었고 원인 병원체를 밝힌 것은 매우 중요한 의미 를 갖는다고 할 수 있으며 이 결과를 통해 국내 지하수
의 바이러스 오염실태와 오염원으로부터 지하수 시설을 보호하고 관리하는 체계 등의 중요성과 필요성을 제시하 고 식품제조용수의 철저한 관리를 통하여 국내에서 발생 하는 바이러스성 식중독 관리를 위한 기초 자료로 활용 될 수 있을 것이다.

\section{참 고 문 헌}

1) Chikhi-Brachet R, Bon F, Toubiana L, Pothier P, Nicolas JC, Flahault A, et al. Virus diversity in a winter epidemic of acute diarrhea in France. J Clin Microbiol 2002;40:4266-72.

2) Fankhauser RL, Monroe SS, Noel JS, Humphrey CD, Bresee JS, Parashar UD, et al. Epidemiologic and molecular trends of "Norwalk-like viruses" associated with outbreaks of gastroenteritis in the United States. J Infect Dis 2001;186:1-7.

3) Kim SH, Cheon DS, Kim JH, Lee DH, Jheong WH, Heo YJ, et al. Outbreaks of gastroenteritis that occurred during school excursions in Korea were associated with several waterborne strains of norovirus. J Clin Microbiol 2005;43:4836-9.

4) Lee SG, Jheong WH, Suh CI, Kim SH, Lee JB, Jeong YS, et al. Nationwide groundwater surveillance of noroviruses in South Korea, 2008. Appl Environ Microbiol 2011;77:1466-74.

5) Bon F, Ambert-Balay K, Giraudon H, Kaplon J, Le Guyader S, Pommepuy M, et al. Molecular epidemiology of caliciviruses detected in sporadic and outbreak cases of gastroenteritis in France from December 1998 to February 2004. J Clin Microbiol 2005;43:4659-64.

6) Maunula L, Miettinen IT, von Bonsdorff CH. Norovirus outbreaks from drinking water. Emerg Infect Dis 2005;11: 1716-21.

7) Noda M, Fukuda S, Nishio O. Statistical analysis of attack rate in norovirus foodborne outbreaks. Int J Food Microbiol 2008;122:216-20.

8) de Wit MA, Koopmans MP, Kortbeek LM, Wannet WJ, Vinjé $\mathrm{J}$, van Leusden $\mathrm{F}$, et al. Sensor, a population-based cohort study on gastroenteritis in the Netherlands: incidence and etiology. Am J Epidemiol 2001;154:666-74.

9) Kaplan JE, Gary GW, Baron RC, Singh N, Schonberger LB, Feldman R, et al. Epidemiology of Norwalk gastroenteritis and the role of Norwalk virus in outbreaks of acute nonbacterial gastroenteritis. Ann Intern Med 1982;96:756-61.

10) Jiang $X$, Wang $M$, Wang $K$, Estes MK. Sequence and genomic organization of Norwalk virus. Virology 1993;195:51-61. 
11) Lambden PR, Caul EO, Ashley CR, Clarke IN. Sequence and genome organization of a human small round-structured (Norwalk-like) virus. Science 1993;259:516-9.

12) Maguire AJ, Green J, Brown DW, Desselberger U, Gray JJ. Molecular Epidemiology of Outbreaks of Gastroenteritis Associated with Small Round-Structured Viruses in East Anglia, United Kingdom, During the 1996-1997 Season. J Clin Microbiol 1999;37:81-9.

13) Belliot G, Noel JS, Li JF, Seto Y, Humphrey CD, Ando T, et al. Characterization of capsid genes, expressed in the baculovirus system, of three new genetically distinct strains of "NorwalkLike Viruses". J Clin Microbiol 2001;39:4288-95.

14) Green SM, Dingle KE, Lambdeb PR, Caul EO, Ashley CR, Clarke IN. Human enteric Caliciviridae: a new prevalent small round-structured virus group defined by RNA-dependent RNA polymerase and capsid diversity. J Gen Virol 1994;75:1883-8.

15) Ando T, Mulders MN, Lewis DC, Estes MK, Monroe SS, Glass RI. Comparison of the polymerase reagion of small round structured virus strains previously classified in three antigenic types by solid-phase immune electron microscopy. Arch virol 1994;135:217-26.

16) Okada M, Ogawa T, Kaiho I, Shinozaki K. Genetic analysis of noroviruses in Chiba Prefecture, Japan, between 1999 and 2004. J Clin Microbiol 2005;43:4391-401.

17) Park KS, Jeong HS, Baek KA, Lee CG, Park SM, Park JS, et al. Genetic analysis of norovirus GII.4 variants circulating in Korea in 2008. Arch Virol 2010;155:635-41.

18) Lee H, Kim M, Lee JE, Lim M, Kim M, Kim JM, et al. Investigation of norovirus occurrence in groundwater in metropolitan Seoul, Korea. Sci Total Environ 2011;409:2078 -84 .

19) Gallay A, De Valk H, Cournot M, Ladeuil B, Hemery C, Castor $\mathrm{C}$, et al. A large multi-pathogen waterborne community outbreak linked to faecal contamination of a groundwater system, France, 2000. Clin Microbiol Infect 2006;12:561-70.

20) Lee C, Kim SJ. The genetic diversity of human noroviruses detected in river water in Korea. Water Res 2008;42:4477-84.

21) Kojima S, Kageyama T, Fukushi S, Hoshino FB, Shinohara M,
Uchida K, et al. Genogroup-specific PCR primers for detection of norwalk-like viruses. J Virol Methods 2002;100:107-14.

22) Lee SG, Lee SH, Park SW, Suh CI, Jheong WH, Oh S, et al. Standardized positive controls for detection of norovirus by reverse transcription PCR. Virol J 2011;8:260.

23) Greenberg HB, Valdesuso J, Yolken RH, Gangarosa E, Gary W, Wyatt RG, et al. Role of Norwalk virus in outbreaks of nonbacterial gastroenteritis. J Infect Dis 1979;139:564-8.

24) Lopman B, Vennema H, Kohli E, Pothier P, Sanchez A, Negredo A, et al. Increase in viral gastroenteritis outbreaks in Europe and epidemic spread of new norovirus variant. Lancet 2004;363:682-8.

25) Noel JS, Fankhauser RL, Ando T, Monroe SS, Glass RI. Identification of a distinct common strain of "Norwalk-like viruses" having a global distribution. J Infect Dis 1999;179: 1334-44.

26) White PA, Hansman GS, Li A, Dable J, Isaacs M, Ferson M, et al. Norwalk-like virus 95/96-US strain is a major cause of gastroenteritis outbreaks in Australia. J Med Virol 2002;68: 113-8.

27) Huh JW, Kim WH, Moon SG, Lee JB, Lim YH. Viral etiology and incidence associated with acute gastroenteritis in a 5-year survey in Gyeonggi province, South Korea. J Clin Virol 2009; 44:152-6.

28) Gallimore CI, Iturriza-Gomara M, Xerry J, Adigwe J, Gray JJ. Inter-seasonal diversity of norovirus genotypes: emergence and selection of virus variants. Arch Virol 2007;152:1295-303.

29) Jung JH, Yoo CH, Koo ES, Kim HM, Na Y, Jheong WH, et al. Occurrence of norovirus and other enteric viruses in untreated groundwaters of Korea. J Water Health 2011;9:544-55.

30) Koh SJ, Cho HG, Kim BH, Choi BY. An outbreak of gastroenteritis caused by Norovirus-contaminated groundwater at a waterpark in Korea. J Korean Med Sci 2011;26:28-32.

31) Kukkula M, Arstila P, Klossner ML, Maunula L, Bonsdorff $\mathrm{CH}$, Jaatinen P. Waterborne outbreak of viral gastroenteritis. Scand J Infect Dis 1997;29:415-8.

32) Rao VC, Metcalf TG, Melnick JL. Human viruses in sediments, sludges, and soils. Bull World Health Organ 1986;64:1-13. 